\title{
A Critical Discourse Analysis of Self- presentation through the Use of Cognitive Processes Associated with We
}

\author{
Inès Ghachem \\ Department of English, Faculty of Letters and Humanities, Sfax, Tunisia
}

\begin{abstract}
This article explores the relationship between discourse structures and self-presentations in mediatised political discourse. By drawing on critical discourse analysis and transitivity from Halliday's systemic functional linguistics, the article analyses transitivity patterns and more specifically the cognitive process types. This paper illustrates how the use of cognitive process and the four moves in the ideology square are affected by the fact that the articles were written by politicians to be published in the media. The two articles analysed are newspaper articles jointly written by Heads of State. The analysis of the use of cognitive process types reveals positive self-presentation through fostering a representation of controversy-free experience and vision of the issues raised.
\end{abstract}

Index Terms - critical discourse analysis, cognitive process types, mediatised political discourse, negative other-presentation, positive self-presentation

\section{INTRODUCTION}

This study draws on critical discourse analysis (hereafter CDA) and on tools from Halliday's Systemic Functional Linguistics (henceforth SFL) to analyse self-representation in mediatised political discourse. The data analysed consists of two articles. The first article (A1) dating April 15 ${ }^{\text {th }}$, 2011 was written by President Barack Obama, PM David Cameron and the French president Nicolas Sarkozy. The second article (A2) was written by the USA president Barack Obama and the British Prime Minister David Cameron for the British newspaper The Times dating May $24^{\text {th }}, 2011$. Both the context and the genre of the data analysed were taken into account in this CDA analysis of self-presentation. The analysis starts from the fact that We/Us are not one person to analyse the use of cognitive process in selfpresentation. Hence, this piece of research analyses not only how the writers of the two articles present Us, but also the backgrounding of differences through answering the following questions:

- What does the cognitive process used reveal about the writers' experience of what they write about?

- In the 'absence' of Them, how are We presented?

- What does the absence of "we think" tell about the kind of world the writers write about?

These questions are answered building on the analysis of the transitivity patterns in the data and more specifically the cognitive processes used. The Heads of State's use of cognitive process associated with we unveils their expressions of their experience of the worlds around them and how they present themselves and the others.

In addition to the introduction and the conclusion, this article is made up of three sections. The first section provides a short survey of the theoretical background on which this study draws. From SFL, transitivity is reviewed as the analytical tool used in the analysis of self-presentation. The next section presents the data analysed with reference to the context in which the articles were written. The fourth section is the discussion of the findings within the theoretical framework reviewed in the following section.

\section{THEORETICAL UNDERPINNINGS}

This piece of research does not aim at theorising about the concepts it cites. Accordingly, this section provides a short review of the concepts drawn upon to answer this study's research questions and interpret its findings.

\section{A. Critical Discourse Analysis}

Though in different terms, and from different points of view, most of us deal with power, dominance, hegemony, inequality, and the discursive processes of their enactment, concealment, legitimation and reproduction. And many of us are interested in the subtle means by which text and talk manage the mind and manufacture consent, on the one hand, and articulate and sustain resistance and challenge, on the other. (Van Dijk, 1993, p. 132 quoted in Titscher et al., 2007, p. 147)

Critical discourse analysis, also called critical discourse studies, is a field of multidisciplinary research. T. A. Van Dijk's quote points to one of the distinctive features of CDA. CDA includes approaches that share common concerns which they tackle from different perspectives. Van Dijk's quote also highlights the importance of CDA in the analysis 
of discourse understanding and production and how it relates discourse and society. Literature on CDA, its origins, principles and ongoing development include Chouliaraki and Fairclough (2005), Fairclough (1992, 1997, 2003), Fairclough and Wodak (1997), Van Dijk (1993, 1995, 2001) and Titscher et al. (2007), Wodak and Chilton (2005) and Wodak and Meyer (2004) among others.

In their Discourse and Late Modernity, Chouliaraki and Fairclough (2005) locate CDA in critical social science and critical research on social change in contemporary society. Their view is that both fields affected and at the same time are affected by CDA. In fact, this dialectical relationship is characteristic of CDA as it draws on other fields of research and schools of thought and at the same time it contributes to them. Critical linguistics and SFL are two other fields that CDA is influenced by and to which CDA studies bring more insight (Fowler, 1998; Fairclough \& Wodak, 1997; Wodak \& Meyer, 2004; Matthiessen, 2009).

\section{B. The Contextual Strategy of Positive Self-presentation and Negative Other-presentation}

Positive self-presentation and negative other-presentation are two complementary strategies (Van Dijk, 1993). These two strategies focus on participants as social groups rather than individuals (Van Dijk, 2009). According to Oktar (2001, p. 344) ideology is an important "determining factor in the organization of discourse in terms of social representation of us versus them; that is, what we are, what we typically do, what our aims and values are in relation to them, and what they are, what they typically do, what their aims and values are in relation to us."

The analysis of ideological square which is made of these four moves (Oktar, 2001, p. 319)

1. Express/emphasize information that is 'positive' about us.

2. Express/emphasize information that is 'negative' about them.

3. Suppress/de-emphasize information that is 'positive' about them.

4. Suppress/de-emphasize information that is 'negative' about us.

is part of what Van Dijk sees as the need "to relate properties of discourse with these underlying, socially shared, representations, which group members use as a resource to talk about (members) of other groups"(Van Dijk, 2009, p. 78).

In this study, the analysis of the use of cognitive processes associated with 'we' reveals not only how the writers categorise Us and Them, but also their judgement of Us as good and Them as bad.

\section{Political Discourse/Media Discourse: Mediatised Political Discourse}

The emergence of medialized politics is sometimes seen as the colonization of politics by the media, and sometimes seen as the colonization of the media by politics.

Fairclough (1995, p. 200)

In addition to the impact of context on discourse production and understanding there is genre. Fairclough's (1995) quote points to mediatised political discourse as the outcome of belonging to the two genres of media discourse and political discourse. This is the case of the article analysed in this piece of research. Since it was written by two Heads of State it is political discourse and since it was published in a newspaper it is media discourse.

For Fairclough, what is crucial is that the "genres of mass media do not at all neatly correspond to the genres of politics, and this lack of fit is a source of constant tension and difficulty for politicians" (1995, p. 184). Fairclough refers to the tension the genres of media and politics and their manifestation in politicians' work on self-presentation (image) in the media. From another perspective, writing about language in the news, Fowler sheds light on the status of the news as "an industry with its own commercial self-interest" $(1998$, p. 2) which from a media perspective rules its relation to politics and society.

The argument that "because the institutions of news reporting and representation are socially, economically and politically situated, all news is always reported from some particular angle" (Fowler, 1998, p. 10) is refers to what media and discourse share something in common: representation. In other words, there is no neutral writing and media discourse is an interpretation of reality rather than a mere representation (Macdonald, 2003). Fowler's view is that events and ideas cannot ne communicated neutrally "because they have to be transmitted through some medium with its own structural features, and these structural features are already impregnated with social values which make up a potential perspective on events" (1998, p. 27).

\section{Transitivity Analysis}

CDA is not only about connecting between discourse and society, but also is concerned with the actual analysis of the discourse itself: "[c]ritical discourse analysis is very much about making connections between social and cultural structures and processes on the one hand, and properties of text on the other" (Fairclough and Wodak, 1997, p. 277). This second task is carried out through using tools from, for example, SFL. Given that this article examines self representation, it looks at transitivity. Literature about SFL and its development out of Firthian linguistics include Halliday (1994), Halliday and Matthiessen (2004) and Halliday and Webster (2009). According to Halliday's SFL, language simultaneously and continuously performs three functions. Transitivity analysis falls within the ideational metafunction; how meaning is embodied in the clause through language users' expressions of their experience of the worlds around them. Transitivity is a semantic concept that refers to the way meaning is represented in a clause. Transitivity analysis reflects not only the ideas expressed in the clause, but also the participants world views: "one and 
the same text may offer alternative models of what would appear to be the same domain of experience" (Halliday \& Matthiessen, 2004, p. 173).

The following is a short summary of the three main types of process in the transitivity system in addition to three others standing on the interface:

1. Material clauses are concerned with participants' experience of the material world and have the structure of Actor + Material process + Goal. The Actor is the participant that brings about through time change leading to an outcome which is different from the initial stage of the action. The second participant, the Goal, is an inherent participant in transitive clauses. Other participants associated with material processes are Scope, Recipient, Client and Attribute. Examples of material clauses in the article are:

A2: So as [Actor:] we [Process: material:] meet [Goal:] today, facing immense economic, social and strategic challenges, it is natural that once again [Actor:] our two nations [Process: material:] join [Goal:] together in common cause.

A1: [Actor:] Britain, France and the United States [Process: material:] will not rest [Goal:] until the United Nations Security Council resolutions have been implemented and the Libyan people can choose their own future.

2. Mental clauses are concerned with participants' experience of the world. In mental clauses the Senser is the participant "endowed with consciousness" (Halliday and Matthiessen, 2004, p. 201) and the Phenomenon is the thing, the fact or the act that is sensed. As for the types of sensing there are four sub-types: perceptive, cognitive, desiderative and emotive. Examples of verbs serving as Process in mental clauses in the article are:

A2: [Senser:] We want [Process: mental:emotive:] to encourage [Phenomenon:] more of this exchange of capital, goods and ideas.

A1: [Senser:] We [Process:mental: cognitive:] know [Phenomenon:] from bitter experience what that would mean.

3. Relational clauses serve through processes of being and processes of having. Of the type ' $x$ is $a$ ', ' $x$ has $a$ ' or ' $x$ is at $a$ ' (Halliday and Matthiessen, 2004, p. 216), relational clauses can be attributive where ' $a$ is an attribute of $x$ ' or identifying where ' $a$ is the identity of $x$ '. Examples of relational clauses from the article are:

A2: Now [Token:] we [Process:relational: identifying:] are [Value:] two different countries || but [Token:] our destination [Process: relational:identifying:] must be [Value:] the same: strong and stable growth, reduced deficits and reform of our financial systems - so that they will never again be open to the abuses of the past.

A2: Yes, [Carrier:] we [Process: relational: attributive:] are [Attribute:] mindful of the risks $\|$ and [Attribute:] aware of the uncertainties.

4. Besides there are three processes located at the boundaries between the three above process types. Behavioural clauses are placed between mental and material clauses. Behavioural processes are processes of typical human behaviour (physiological and psychological). The participant associated with behavioural processes is the Behaver. Verbal clauses are clauses of saying and are located between relational and mental process. The participants associated with verbal processes are the Sayer and the addressee of the Verbiage is the Receiver. Existential clauses from their part, "construe a participant [the Existent] involved in a process of being" (Martin et al., 1997, p. 109) and are located between material and relational process. Examples of these three process types are:

A2: [Behaver:] We [Process: behavioural:] look at [Behaviour:] the world in a similar way

A2: So this week [Sayer:] we [Process: verbal:] will reaffirm [Verbiage:] our commitment to strong collaboration between our universities and research facilities.

A2: But [Existent:] we [Process: existential:] stand together, optimistic and confident

\section{CORPUS DESCRIPTION}

The corpus analysed consists of two articles written by more than one Head of State:

- A1 is the only article jointly written by President Barack Obama, PM David Cameron and the French president Nicolas Sarkozy. The full article posted on number10.gov counts 791 words. A1 appeared April $15^{\text {th }}, 2011$ on the International Herald Tribune and other media as an editorial jointly written by Barack Obama, David Cameron and Nicolas Sarkozy dealing with the events in Libya. Table 2 displays details about A1.

- A2 is to date the only article jointly written by just Barack Obama and David Cameron. The article can be accessed online on three websites two of which offer free access. The full article posted on number10.gov counts 1168 words. Table 3 displays details about A2 in each of the three sites. A2 is an article that President Barack Obama and PM David Cameron have written for the Times newspaper. The newspaper article was written on the occasion of President Obama's second official state visit to the UK which was 24-26 May 2011. The first visit Obama did to the UK was in 31 March - 2 April 2009 when Gordon Brown was the PM which means that the May 2011 visit is the first visit since David Cameron became PM.

Below is a short presentation of the three Heads of State: (until 2013) 
TABLE 1

A SHORT PRESENTATION OF THE THREE HEADS OF STATE

\begin{tabular}{|l|l|l|l|}
\hline & Barack Obama & David Cameron & Nicolas Sarkozy \\
\hline Political position & The $44^{\text {th }}$ USA president & The UK's Prime Minister & The $23^{\text {rd }}$ president of France \\
\hline Political party & The Democratic Party (DP) & The Conservative Party (CP) & The Union for a Popular Movement \\
\hline Terms in office & $\begin{array}{l}\text { First term: } 2008-2012 \\
\text { Second term: 2012- }\end{array}$ & First term: 2010- & One term: $2007-2012$ \\
\hline $\begin{array}{l}\text { Distinctive } \\
\text { information }\end{array}$ & $\begin{array}{l}\text { The first African American } \\
\text { president in the history of the } \\
\text { USA. }\end{array}$ & $\begin{array}{l}\text { - The youngest British PM since 1812. } \\
\text { Leads a Conservative / Liberal Democrat } \\
\text { coalition government }\end{array}$ & $\begin{array}{l}\text { The first president to serve only one } \\
\text { term in more than thirty years. }\end{array}$ \\
\hline
\end{tabular}

TABLE 2

DETAILS ABOUT A1

\begin{tabular}{|l|l|l|}
\hline Title & Place of publication & Date of publication \\
\hline $\begin{array}{l}\text { Pathway } \\
\text { to peace }\end{array}$ & $\begin{array}{l}\text { The official site of the British PM's office at: } \\
\text { http://www.number10.gov.uk/news/joint-article-on-libya-the-pathway-to-peace/ }\end{array}$ & Friday 15 April 2011 \\
\hline $\begin{array}{l}\text { Pathway } \\
\text { to peace }\end{array}$ & The New York Times site at: http://www.nytimes.com/2011/04/15/opinion/15iht-edlibya15.html?_r=0 & April 15 ${ }^{\text {th }}, 2011$ \\
\hline
\end{tabular}

TABLE 3

DETAILS ABOUT A2

\begin{tabular}{|l|l|l|}
\hline Title & Place of publication & Date of publication \\
\hline $\begin{array}{l}\text { Not just special, but an } \\
\text { essential relationship }\end{array}$ & $\begin{array}{l}\text { The Times website at: } \\
\text { http://www.thetimes.co.uk/tto/opinion/columnists/article3033133.ece }\end{array}$ & Tuesday May 24 $^{\text {th }}, 2011$ \\
\hline An essential relationship & $\begin{array}{l}\text { The official site of the British PM's office at: } \\
\text { http://www.number10.gov.uk/news/prime-minister-and-president-obama-article-an- } \\
\text { essential-relationship/ }\end{array}$ & Monday May 23 $^{\text {rd }}, 2011$ \\
\hline An essential relationship & $\begin{array}{l}\text { The BCP 's official website at: } \\
\text { http://www.conservatives.com/News/Articles/2011/05/David_Cameron_and_President } \\
\text { _Obama_an_essential_relationship.aspx }\end{array}$ & Tuesday May 24 ${ }^{\text {th }, 2011}$ \\
\hline
\end{tabular}

\section{FINDINGS AND ANALYSIS}

This present piece of research aims to carry a critical discourse analysis of a mediatised political discourse through the analysis of the transitivity patterns used and more specifically focus on cognitive processes. The first step in the analysis of self-presentation in the corpus is the definition of what 'we' refers to. When the absence of ' $I$ ' is expected in articles written by more than one person, 'we' has more than one reference. The terms 'inclusive we' and 'exclusive we' are used following Levinson's (1989) definition. With reference to studies about the uses of 'we' (Levinson, 1989; Zupnik, 1994), in A1 there are:

- The inclusive we:

- The writers writing on behalf of:

- Their respective countries (our countries, Britain, France and the United States).

- Others (NATO allies and coalition partners, Europe, the region, the world)

- The exclusive we:

○ The writers only write about themselves: we.

$\circ$ The United States, France and Britain.

In A2, however, there are:

- The inclusive we:

$\circ$ The writers and the newspaper readers.

$\circ$ The writers writing on behalf of:

- Their respective governments (our actions, our efforts).

- Their respective countries (our two nations, the United Sates and Britain).

- Others (people around the world).

- The exclusive we:

- The writers only write about themselves: Barack Obama and David Cameron (both of us).

$\circ$ British and Americans (our two leaders at the time, our interests and values).

Among the uses of the inclusive we, it is not probable that it refers to the newspaper. The political position of the two writers does not categorise them in the same group as newspaper journalists since in newspapers journalists use we with reference to their status as members of the newspaper. Such use of we is also understood with reference to with whom we are related. Extract from A1 and A2, Figures 1 and 2 schematise to whom We are and the other partners with whom we relates. Fig. 2 schematises most of the links established in A2 among we and with whom it is related. The three circles in the Fig. 2 shows three spheres. Two of them, group "both of us", "we", "our people" and "us". The wider sphere includes those presented as related to "we". The net of ties end up liking "both of us" and "we" to the "world". In sum, those included in A2 presents we as relating to friends and foes. A similar conclusion is drawn from Fig. 1 
where although the writers do not refer to themselves in person, we on the one hand related to e.g. "the UN" and "the international community" and on the other hand to "Colonel Qadhafi".

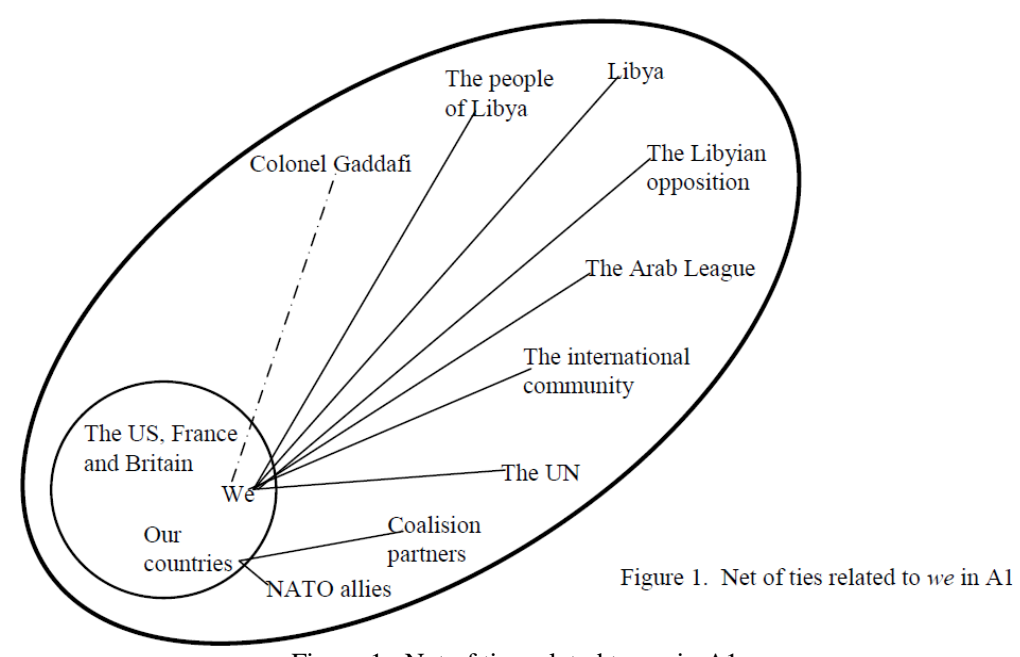

Figure 1. Net of ties related to we in A1

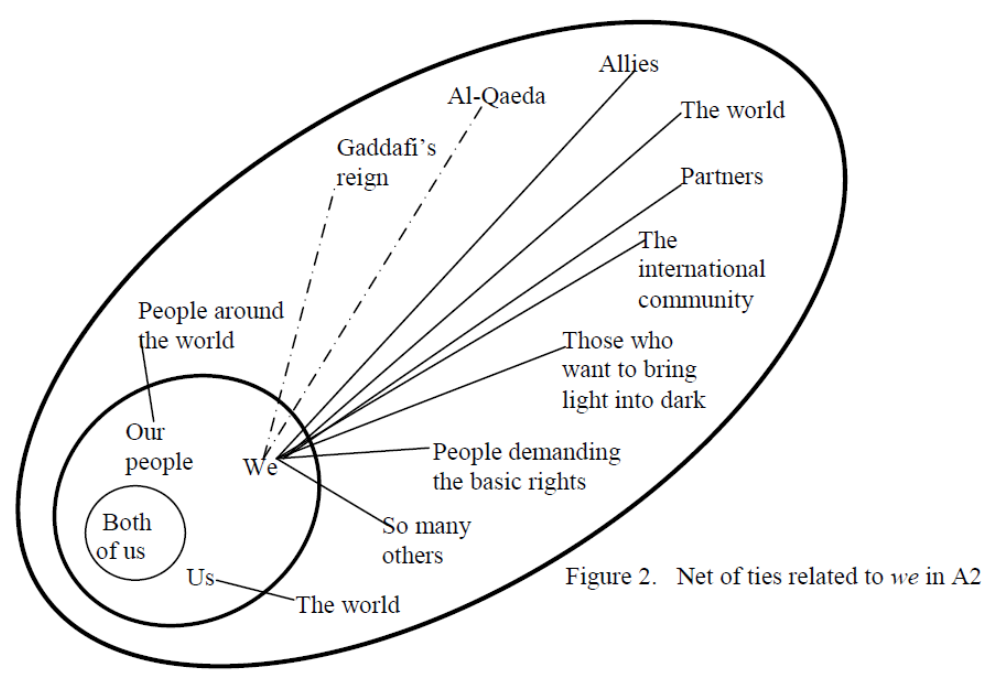

Figure 2. Net of ties related to we in A2

Building on how the writers categorise those they invoke in their article, the analysis of the process types associated with we serves to examine how Us are presented. Table 5 displays the uses of the six process types in A2 and shows that half of the 62 processes are material processes. Second in use are mental process types with 13 occurrences. In third place come relational process types with 12 occurrences. The three other process types have six occurrences. Among the mental process types used, cognitive process types are the most used. In A1, as Table 4 displays, out of the eleven process types used, nine are material and two are cognitive process types.

TABLE 4

TRANSITIVITY AND PRESENTATION IN A1

\begin{tabular}{|c|c|c|c|c|c|c|c|c|c|c|c|}
\hline Process & \multicolumn{2}{|c|}{ Relational } & Material & \multicolumn{4}{|c|}{ Mental } & Beh. & Ver. & Ext. & Total \\
\hline \multirow{3}{*}{$\begin{array}{l}\text { Number of } \\
\text { occurrences }\end{array}$} & Id. & Att. & \multirow{3}{*}{9} & Per. & Cog. & Des. & Emo. & \multirow{3}{*}{0} & \multirow{3}{*}{0} & \multirow{3}{*}{0} & \multirow{3}{*}{11} \\
\hline & 0 & 0 & & 0 & 2 & 0 & 0 & & & & \\
\hline & \multicolumn{2}{|l|}{0} & & \multicolumn{4}{|c|}{2} & & & & \\
\hline
\end{tabular}


TABLE 5

TRANSITIVITY AND PRESENTATION IN A2

\begin{tabular}{|c|c|c|c|c|c|c|c|c|c|c|c|}
\hline Process & \multicolumn{2}{|c|}{ Relational } & Material & \multicolumn{4}{|c|}{ Mental } & Beh. & Ver. & Ext. & Total \\
\hline \multirow{3}{*}{$\begin{array}{l}\text { Number of } \\
\text { occurrences }\end{array}$} & Id. & Att. & \multirow{3}{*}{31} & Per. & Cog. & Des. & Emo. & \multirow{3}{*}{1} & \multirow{3}{*}{2} & \multirow{3}{*}{3} & \multirow{3}{*}{62} \\
\hline & 8 & 4 & & 5 & 7 & 0 & 1 & & & & \\
\hline & \multicolumn{2}{|l|}{12} & & \multicolumn{4}{|c|}{13} & & & & \\
\hline
\end{tabular}

Note (in Table 4 and Table 5):

Id. = Identifying Cog. = Cognitive Beh. = Behavioural

Att. $=$ Attributive $\quad$ Des. $=$ Desiderative $\quad$ Ver. $=$ Verbal

Per. $=$ Perceptive $\quad$ Emo. $=$ Emotive $\quad$ Ext. $=$ Existential

In both $\mathrm{A} 1$ and $\mathrm{A} 2$ the writers use we with cognitive process types when presenting themselves with reference to past experience. In A2 (1) below, Barack Obama and David Cameron "recall" past memories "like so many others" which mean that they present them as a shared past experience by an inclusive we. The inclusive use of we fixes the writers, the readers and others within the same background knowledge about one specific historical era of which they share memories:

A1 (1) And because he has lost the consent of his people any deal that leaves him in power would lead to further chaos and lawlessness. We know from bitter experience what that would mean. Neither Europe, the region, or the world can afford a new safe haven for extremists.

A2 (1) Both of us came of age during the 1980s. Like so many others, we recall a turbulent decade that began with armies confronting each other across a divided Europe and ended with the Berlin Wall coming down, millions freed from the shackles of communism and human dignity extended across the continent.

In A1 (1) the knowledge on which Barack Obama, David Cameron and Nicolas Sarkozy build their understanding of the events is a knowledge we do not only share, but also agree on. In other words, past memories and experience are presented and used to understand present events and are also what highlights the positive image of we as sharing memories and experience as members of the inclusive we.

In A2 (2), what "what we both need and what we both believe" is an argument which is presented as a fact stirring no disagreement or difference in interpretation:

A2 (2) It is a perfect alignment of what we both need and what we both believe. And the reason it remains strong is because it delivers time and again. Ours is not just a special relationship, it is an essential relationship - for us and for the world.

Barack Obama and David Cameron root the US-British relationship in what both sides 'need' and 'believe'. The association of need and believe shows the two writers as having a 'good' sense of judgement of what is needed and associate it is 'strong' belief in that it is what is needed. The use of belief and the commitment it expresses (Fetzer, 2008) presents the two Heads of State as two leaders having a strong commitment to the US-British relations. Moreover, the fact that the article appeared in a newspaper with 'Not just special, but an essential relationship' as headline refers to the concern with presenting and justifying (the use of because) their (Obama and Cameron's) vision of the kind of relationship the two countries enjoy.

The next use of cognitive process types like relates to current events and issues. With reference to the global economy and the economic situation since 2008, Obama and Cameron's attitude is that "our destination must be the same":

A2 (3) Governments do not create jobs: bold people and innovative businesses do. We know that our nations are selfreliant and infused with the entrepreneurial spirit.

The first clause in A2 (3) tells about the economic policy which the two Heads of State endorse. For Obama and Cameron the policy to face unemployment is one built on liberal economic management where job creation is the task of people and business and collaborations between the two countries. Such view is judged positive and fit for the two countries as the writers bring out the knowledge we have that "our nations are self-reliant and infused with the entrepreneurial spirit". Their knowledge is backed by an enumeration of the distinctive features of the economic foundations of the two economies which is part of presenting knowledge as facts and facts as knowledge the readers are introduced to or remembered of. Drawing on what we value reinforces not only the two Heads of State's own positive image but also that of the countries they lead.

Positive self-presentation through using cognitive processes relates to widening the scope the inclusiveness of we. In example A2 (4) the topic dealt with is security. Like the other topics dealt with in A1 and A2, current events are related to us though foregrounding what our positive values. In the time A2 was written (May 24 ${ }^{\text {th }}, 2011$ ), the "death of Osama bin Laden" (May 2 ${ }^{\text {nd }}, 2011$ ), the "events in the Arab world and Middle East" (starting in 2010) and "our actions in Libya" (starting March $19^{\text {th }}, 2011$ ) were the recent events and the events underway:

A2 (4) What we are seeing there is a groundswell of people demanding the basic rights, freedoms and dignities that we take for granted.

After enumerating what we did dealing with Al-Qaeda and its affiliates and "our mission in Afghanistan", Obama and Cameron turn to express what "we need to understand". What is noticed is that there are no cognitive processes used to express the writers' understanding of "those who wish to do us harm". With reference to Fig. 1 and Fig. 2, two of the sides to whom the writers 'relate' we are Al-Qaeda and Colonel Gaddafi's regime. These two sides make up 
Them and since they are absent in the articles (in the sense that they are passive participants and not the writers) it is the three Heads of State who present them. What the others' presentation highlights is the threat Them present. Details foregrounded in A1 and A2 can be said to favour a particular understanding of Them. Them are framed as a threat which death, in the case of Bin Laden, is an occasion to reaffirm Our achievements.

Also categorised among Them is Colonel Gaddafi and his regime. The focus on the events in Libya and reference to Gaddafi as a Colonel whose regime is a threat to the Libyan people raises the following question: what do We have to do with the Libyan people and how is Colonel Gaddafi's regime a threat to Us (the USA, Britain and France)? The answer present in A1 and A2 is: ideology. Once grouped in the same category, both Al-Qaeda and Colonel Gaddafi's regime are presented as sharing one common feature: what they stand for is different from Ours. Them are presented as roadblocks to freedom. In terms of ideology, Al-Qaeda and its affiliates' "poisonous ideology and the violence that flows from it", the "narrative of separateness and victimhood that al-Qaeda's ideology feeds off" and Colonel Gaddafi's regime crashing people's aspirations leaves no room for a positive other-presentation. While the scope of endorsing AlQaeda's ideology is restricted to Them, the judgement and subsequent refusal of Their ideology is that of a wider group.

A1 (2) We must never forget the reasons why the international community was obliged to act in the first place. As Libya descended into chaos with Colonel Qadhafi attacking his own people, the Arab League called for action. The Libyan opposition called for help. And the people of Libya looked to the world in their hour of need.

The wide inclusiveness of we results in a wide Senser of the cognitive processes. In A1 (2) like with 'recall', the writers draw on the readers' knowledge to, first, relate with the audience on the same common ground knowledge, and, second, link the writers' positive imager to that of the readers'. Hence, what "We must never forget" is another example of Us growing to include the world and exclude Them. Facing Them, Our actions and use of force is presented as dictated by Our values and interests:

A2 (5) We are reluctant to use force but when our interests and values come together we know that we have a responsibility to act.

The justification the writers advance for using force first distinguishes them from the violence of Them and second favours an understanding that they act out of responsibility. In A2 and especially in A1, the focus on the recent event with the absence of what we think of our actions is compared to that focus on the positive results of our actions. We are the ones who judge what is 'good' and what is 'bad' which end up presenting Our actions as being 'good' and Theirs as 'bad'.

In A1 and A2, positive self-presentation leaves no room for disagreement. While negative other-presentation builds on their ideology and their actions, the use of force by we turns to be a source of negating negative self-presentation and turn it to a good thing we do. The analysis of cognitive process types unveils the writers' strategy in keeping the ideological polarisation between Us 'good' and Them as 'bad' as a kind of mental presentation we share and is undisputable.

'We think'

Another point that this study tackles is the absence of 'we think'. In both A1 and A2 the writers do not use the cognitive process type 'think' which raises the question: why is 'we think' absent?

In the interpretation of the absence of 'we think', I refer to two studies: Fetzer (2008) and Ghachem (2011). The following is a short summary of the findings of the two studies:

- With reference to the quantitative analysis of cognitive verbs (cf. Table 3, Fetzer, 2008, p. 392), the speaker's use of "I think" and its negative form is by far the most prominent use followed by "I believe" and its negative form. Second in number of occurrences is the use of think and believer to speak about what the others think and believe.

- The analysis of David Cameron's 2010 pre-election speeches (Ghachem, 2011) reveals that the most used process types are mental, then material then relational with the cognitive processes counting more than two third of the mental processes. In the use of mental processes when I (David Cameron) is the Senser it is linked with mental processes mainly of "believe", "think" and "want".

It is important to mention that the two studies referred to both analyse political discourse, yet they differ from this study in the sub-genre (spoken or written) and whose discourse is analysed. Nevertheless, the findings can be referred to in the sense that, like here, they analyse language use. Second, and to our knowledge; the absence of analysis of the discourse of the three Heads of State or two of them emphasis the analysis of their discourse with reference to how they use the language and more specifically cognitive process types.

In A1 and A2, the absence of 'we think' is seen keeping the ideological polarisation between Us and Them. The fact that the US president, the British PM and the French president belong to three political parties implies that they have different ideologies. The use of 'we think' may become ambiguous: of the three leaders' ideologies which one is presented? Second, as jointly writing, A1 and A2, how comes that they share everything including the same ideology? Within the scope of this present paper, the answer to these two questions relates to the use of cognitive process types associated with we and the absence of 'we think'. The absence of 'we think' can be interpreted in alignment with the conclusion drawn from such use of transitivity patterns i.e. the writers gives no signs of disagreement among themselves and leaves no room for the readers to disagree with their discourse and to judge what they think of as right or wrong. The three ideologies held by each of the three Heads of State are presented on the image of Us, one coherent and disagreement-free ideological group. The distinction draws is between Our ideology and Their ideology and not 
between the ideologies within Us. The absence of 'we think' reflects an understanding that A1 and A2 are not about what in inside Us but rather the distinction and opposition of Us from/to Them. The absence of what We think of Them leads to no agreement or disagreement of what We think of Them so to judge Our actions as 'good' or 'bad'.

The second interpretation of the absence of 'we think' relate to we. In A1 and A2, if the three sides of we dismantle, then one would be Us and the others would be Them. Accordingly, to whom we relate in Fig. 1 and Fig. 2 would be different. The fact that A1 and A2 are jointly written avoids each of the three Heads of State involved facing each other. The result is their joint definition, categorisation and so presentation of Us and Them. Instead of facing each other, the writers clearly define Them as not We. The distinction of what we do and how they experience the world from the others' actions and ideology keeps with the separation of Us from Them. Besides, it is up to Us to present the others and what they are thought of. The writers do not shock the readers through negative self-presentation and positive otherpresentation. Rather, they keep positive self-presentation through negative other-presentation and the absence of 'we think' avoids negative self-presentation.

Thus, the absence of what We think of and the few cognitive process types used are in tandem with pieces of writings written by more than one Head of State and are genre and context related. The reference to the context as well as the fact that both article were to appear in newspapers are important factors that affect the understanding and the subsequent interpretation of the two articles.

\section{CONCLUSION}

This article has attempted to analyse self-presentation in a political discourse written for the media. Working within CDA as the general theoretical framework, transitivity analysis of an article for the International Herald Tribune written by Barack Obama, David Cameron and Nicolas Sarkozy dating April 15 ${ }^{\text {th }}, 2011$ and a second article for the Times written by Barack Obama and David Cameron dating May $24^{\text {th }}, 2011$ revealed a predominant use of material process compared to the other process types. The delineation of Us and Them categorises the writers as well as the readers (the immediate recipients of the discourse) in the same group. Each Head of State's distinctive understanding of the world are absent on the image of the few cognitive processes used. Presenting We as one coherent and dissidence-free group is built on sharing the same background and understanding of the world around them. Thus, while it is not clearly stated that We share the same ideology, the writers do not include what may be shocking to the readers. Besides, the inclusion of the world (except Them) in we, leaves no one to question Us or to disagree with what we think. The conclusion that can be drawn is that the absence of 'we think' means keeping the unity of Us in both their defence of universal democracy and facing Them. Accordingly, in A2 "we stand for something different" could not be understood to be the ideological differences between Barack Obama and David Cameron. In the absence of what we think of what we stand for, the US, the UK and France are positively presented taking for granted that there are no signs of struggle over power and dominance within we.

\section{ACKNOWLEDGEMENT}

I would like to thank Mr. Juraj Horvath for his interest in my work and for his valuable review of an earlier version of this paper. I would also like to thank Ms. Anita Fetzer for her review of this version of this paper, constructive comments and suggestions. Finally, I would like to thank the anonymous reviewers of the JLTR and JLTR for publishing this paper. None of the names is to be held responsible in any way for the shortcomings of this article.

\section{REFERENCES}

[1] Chouliaraki, L., \& N. Fairclough (2005). Discourse in late modernity. Edinburgh: Edinburgh University Press.

[2] Fairclough, N. (1992). Language and power. London: Longman.

[3] Fairclough, N. (1995). Media discourse. London: Hodder Arnold.

[4] Fairclough, N. (1997). Critical discourse analysis: The critical study of language. London: Longman.

[5] Fairclough, N. (2003). Analysing discourse: Textual analysis for social research. London: Routledge.

[6] Fairclough, N., \& R. Wodak (1997). Critical discourse analysis. In T.A. Van Dijk (ed.), Discourse studies: A multidisciplinary introduction. London: Sage Publications, 258-284.

[7] Fetzer, A (2008). "And I Think That Is a Very Straightforward Way of Dealing With It". The Communicative Function of Cognitive Verbs in Political Discourse. Journal of Language and Social Psychology. 27. 4, 384-396

[8] Fowler, R. (1998). Language in the news. London: Routledge.

[9] Ghachem, I. (2011). Agency framing in David Cameron's (2010) pre-election discourse: A sociocognitive approach, MA dissertation, FLSHS, Tunisia.

[10] Halliday M. A. K., \& C. M. I. M. Matthiessen. (2004). An introduction to functional grammar. London: Hodder Arnold.

[11] Halliday M. A. K., \& J. J. Webster (eds.) (2009). Continuum companion to systemic functional linguistics. London: Continuum.

[12] Halliday, M. A. K. (1994). An introduction to functional grammar. London: Edward Arnold.

[13] Levinson, S. C. (1989). Pragmatics. Cambridge: Cambridge University Press.

[14] Macdonald, M. (2003). Exploring media discourse. London: Hodder Arnold.

[15] Matthiessen, C. M. I. M. (2009). Ideas \& new directions. In M. A. K. Halliday \& J. J. Webster (eds.) Continuum companion to systemic functional linguistics. London: Continuum, 12-58. 
[16] Oktar, L. (2001). The ideological organization of representational processes in the presentation of us and them. Discourse \& Society 12. 3, 313-346.

[17] Titscher, M., M. Meyer, R. Wodak \& E. Vetter (eds.) (2007). Methods of text and discourse analysis. London: Sage Publications.

[18] Van Dijk, T. A. (1993). Principles of critical discourse analysis. Discourse \& Society 4.2, 249-283.

[19] Van Dijk, T. A. (1995). Aims of critical discourse analysis. Japanese Discourse 1.1, 17-27.

[20] Van Dijk, T. A. (2009). Critical discourse studies: A sociocognitive approach. In R. Wodak \& M. Meyer (eds.) Methods of critical discourse analysis. London: Sage, 62-86. Retrieved June $11^{\text {th }}$, 2010 from http://www.discourses.org/OldArticles/Critical\%20discourse\%20studies.pdf.

[21] Van Dijk, T. A. (2001). Critical discourse analysis. In D.T. Schiffrin \& H. Hamilton (eds.), Handbook of discourse analysis. Oxford: Blackwell, 352-371.

[22] Wodak, R., \& M. Meyer (eds.) (2004). Methods of critical discourse analysis. London: Sage Publications.

[23] Wodak, R., \& P. Chilton (eds.) (2005). A new agenda in (critical) discourse analysis. Amsterdam: John Benjamins Publishing Company.

[24] Zupnik, Y. J. (1994). Pragmatics, deixis and political discourse. Journal of Pragmatics 21, 339-383.

Inès Ghachem was born in Mahdia, Tunisia. She holds an MA in Theoretical and Applied Linguistics from the Faculty of Letters and Humanities of Sfax (FLSHS), Tunisia. She is currently working on her PhD thesis for a PhD degree in Theoretical and Applied Linguistics from the FLSHS, Tunisia. Her research interests include Critical Discourse Studies, Mediatised Political Discourse Analysis and the relation between Discourse and Genre. 